\title{
PENINGKATAN COUNSELOR COMPETENCE BAGI CALON GURU KELAS MI dan SD DI ERA INDUSTRI 4.0
}

\author{
Roikhatul Janah \\ STAINU Purworejo, Purworejo, Indonesia \\ Roikhatuljanah30@gmail.com \\ Dhiya Ayu Tsamrotul Ihtiari \\ STAINU Purworejo, Purworejo, Indonesia \\ Tsamrotul.ihtiari@gmail.com
}

\begin{abstract}
Counselor competence is the ability that must be possessed by someone to help others who have problems so the problem is clear. It becomes very important if a prospective class teacher in MI / SD must be able to have this competency. This research focuses on the study of enhancement counselor competence for prospective class teachers in MI and Elementary Schools in the industrial revolution era 4.0 which is a program created bby universities that have been granted admission to elementary schools. The method of this study a literature-based research. The results of study indicate that the Directorate of Islamic Education at the Ministry of Religion has presented all competencies that must be achieved by prospective class teachers. Managerial competence and general skills that must be possessed by prospective teachers in MI /SD classes are in accordance with the needs of a teacher in the industrial revolution era 4.0, namely counselor competence, so that prospective teachers of classes at MI / SD from Islamic tertiary institutions can be said to be able to become suitable class teachers with the industrial revolution era 4.0.
\end{abstract}

Keywords: Counselor Competence; Prospective Class Teachers. 


\section{Abstrak}

Kompetensi konselor merupakan kemampuan yang harus dimiliki seseorang untuk membantu orang lain yang mempunyai permasalahan, sehingga permasalahan dapat terselesaikan. Menjadi sangat penting jika seorang calon guru kelas di MI/SD harus memiliki kompetensi ini. Penelitian ini memiliki fokus pada kajian tentang peningkatan counselor competence bagi calon guru kelas di MI dan SD di era revolusi industri 4.0 yang diselenggarakan oleh perguruan tinggi yang membuka program pendidikan dasar. Metode dalam penelitian ini adalah metode berbasis pustaka. Hasil penelitian ini menunjukkan bahwa Direktorat Pendidikan Islam Kementerian Agama telah menyajikan semua kompetensi yang harus dicapai oleh calon guru kelas. Kompetensi manajerial dan keterampilan umum yang harus dimiliki calon guru kelas MI/SD tersebut sesuai dengan kebutuhan seorang guru di era revolusi industri 4.0 yaitu kompetensi konselor, sehingga calon guru kelas MI/SD yang berasal dari perguruan tinggi keislaman mampu menjadi guru kelas yang sesuai dengan era revolusi industri 4.0.

Kata Kunci: Counselor Competence; Calon Guru Kelas.

\section{A. Pendahuluan}

Revolusi industri 4.0 awalnya dicetuskan oleh professor Klaus Schwab. Klaus merupakan seorang ahli ekonomi sekaligus teknisi yang lahir di Ravensburg, Jerman. Melalui karyanya buku berjudul The Fourth Industrial Revolution mengatakan bahwa revolusi industri 4.0 pada dasarnya akan merubah cara manusia hidup, bekerja, dan berinteraksi satu dengan yang lain (Lase, 2019). Ada empat tahapan revolusi industri, (1) pada abad ke-18 tepatnya pada tahun 1784, revolusi industri 1.0 terjadi dengan adanya peralatan untuk menenun secara mekanis. (2) revolusi industri 2.0 terjadi pada awal abad ke-20, ditandai dengan memperkenalkan alat untuk menghasilkan sesuatu secara massal dengan melakukan pembagian jam kerja. (3) revolusi industri 
3.0 muncul sekitar awal tahun yang ditandai dengan dimulainya pemakaian barang elektronik memanfaatkan teknologi informasi untuk mengoptimalkan produksi suatu barang. (4) revolusi industri 4.0 terjadi pada tahun 2018, era ini merupakan era revolusi industri yang memadukan otomatisasi dan cyber. Pada era inilah industri mulai merambah dunia virtual, dengan bentuk sambungan jaringan manusia, mesin dan data semua sudah ada di manapun atau biasa dikenal dengan nama Internet of Things (IoT) (Lase, 2019).

Pada era revolusi industri 4.0 tidak diperuntukkan hanya untuk sektor industri saja. Melainkan menjadi tuntutan dan tantangan bagi semua sektor yang ada di dunia, tak terkecuali sektor pendidikan. Pendidikan dituntut untuk selalu berkembang menyesuaikan perkembangan jaman. Pada era revolusi industri 4.0 sektor pendidikan mengartikan era ini sebagai istilah umum yang dipakai para pakar pendidikan untuk memberi gambaran tentang integrasi teknologi cyber dalam bentuk fisik maupun tidak ke dalam suatu pembelajaran.(Lase, 2019).

Pendidikan di pada era ini, adalah sebuah gejala yang terjadi akibat reaksi akan apa yang dibutuhkan oleh era ini. Menyelarasakan antara manusia dan mesin agar tercipta penyelesaian atas bermacam permasalahan yang ada dan menciptakan peluang berbagai macam penemuan baru yang bermanfaat untuk memperbaiki kehidupan manusia zaman sekarang (Lase, 2019). Dunwill dalam lase menyebutkan dalam kurun waktu lima sampai tujuh tahun ke depan akan banyak mengalami perubahan. Perubahan yang disebutkan antara lain: (1) berubahnya tata ruang kelas dalam skala besar, (2) perubahan lanskape pendidikan karena dipengaruhi oleh virtual dan augmented reality, (3) fleksibilitas yang diperoleh pendidik maupun peserta didik terkait dengan tugas yang dapat menyediakan sesuatu sesuai dengan gaya belajar masing-masing peserta didik, (4) massive open online course (MOOC) dan sejumlah 
162 | Roikhatul Janah dan Dhiya Ayu Tsamrotul Ihtiari

alternatif untuk sistem pembelajaran online yang akan memiliki dampak pada pendidikan menengah (Lase, 2019).

Era revolusi industri 4.0 mengharuskan calon pendidik mampu mempersiapkan lima kompetensi. Menurut Qusthalani lima kompetensi tersebut antara lain: pertama, kompetensi dasar yang harus dimiliki adalah kompetensi belajar mengajar berdasarkan internet(educational competence);kedua,kompetensi peserta didik yang akan membawa dirinya mempunyai sikap entrepreneurship dengan teknologi dari hasil karya inovasi peserta didik (competence for technological commercialization); ketiga, pendidik memahami berbagai budaya dan menjadi problem solver dalam persoalan pendidikan (competence in globalization); keempat, kompetensi pendidik untuk memprediksi sesuatu yang mungkin akan terjadi dimasa yang akan datang dan bagaimana strategi mengahadapinya, dengan cara berkolaborasi misalnya dengan joint-lecture, joint-research, joint-resources, staff mobility, dan rotasi (competence in future strategies); kelima, kompetensi pendidik untuk memahami semua permasalahan peserta didik terutama permasalahan psikologis akibat perkembangan zaman (counselor competence) (Wahyuni, 2018).

Sebagaimana yang telah diketahui bahwa undang-undang guru dan dosen nomor 14 tahun 2005 menyebut bahwa seorang pendidik atau guru harus memiliki perangkat lengkap yaitu kepandaian berupa pengetahuan, kecakapan berupa keterampilan dan sikap berupa perilaku yang harus terinternalisasi oleh guru maupun dosen ketika melakukan tugas keprofesonalan atau yang sering dimaksud dengan kompetensi (Republik Indonesia, 2005). Selanjutnya, kompetensi tersebut meliputi adalah pedagogik, profesional, kepribadian, dan sosial. Semakin berkembangnya jaman, maka sampailah pada era yang memungkinkan dengan adanya kemajuan teknologi maka otomatisasi di semua bidang akan terjadi. Melalui teknologi dan pendekatan baru yang menggabungkan seluruh aspek mulai dari dunia fisik yang kasat mata, digital, dan biologi secara mendasar dapat mengubah 
interaksi dan pola hidup manusia (Ghufron, 2018). Dengan sesuatu yang baru tersebut sangat mungkin jika seorang pendidik harus berkembang agar memiliki kompetensi tersebut. Tidak bisa terbayangkan jika tugas dan peran guru yang semakin bertambah namun kompetensi yang dimiliki masih sama dengan kompetensi sebelumnya.

Calon pendidik yang akan menjadi guru kelas harus benarbenar menyiapkan dirinya untuk menguasai lima kompetensi sebagai pendidik di era ini. Era ini menitik beratkan pada ekonomi digital, kecerdasan buatan, big data dan robotic. Hal tersebut mengharuskan sektor pendidikan untuk membangun kemampuannya dalam menciptakan sesuatu, cara berpikir kritis, dan menguasai teknologi terkini serta mampu membangun literasi digital(Krjogja, 2018). Maka suatu perubahan dalam dunia pendidikan merupakan suatu keharusan agar selalu sesuai dengan perkembangan zaman. Mulai dari metode pembelajaran sampai kompetensi pendidik juga harus mengalami perkembangan sehingga siswa-siswa yang didik para pendidik di Indonesia mampu bersaing dengan dunia global.

Komptensi guru dalam UU guru dan dosen nomor 14 tahun 2005 pasal 10 ayat 1 (pedagogik, profesional, kepribadian, dan sosial) belum sepenuhnya tercapai oleh setiap guru di Indonesia. Pada tahun 2015 kemendikbud melakukan penilaian terhadap kompetensi guru atau yang bisa dikenal dengan uji kompetensi guru dengan tujuan untuk menilai mutu guru melalui kompetensi pedagogik dan kompetensi profesional yang dimilikinya, hasilnya menunjukkan bahwa rata-rata nasional kompetensi pedagogik dan profesional pendidik di Indonesia ada diangka 53,02, padahal standar kompetensi minimal (SKM) nasional yang ditetapkan diangka 55 (Kementrian Pendidikan Nasional, 2015).

Setelah empat kompetensi guru yang belum tercapai sepenuhnya, tantangan setelahnya terdapat 5 kompetensi guru yang harus disesuaikan dengan era ini. Ada beberapa faktor yang menyebabkan kompetensi yang dimiliki guru di Indonesia rendah 
antara lain tidak sesuainya disiplin ilmu yang dimiliki dengan bidang ajar, jenjang pendidikan guru belum setara dengan sarjana, rekrutmen guru yang belum efektif (Yunus, 2018). Tantangan guru semakin besar, dengan harus menguasai empat kompetensi sesuai UU guru dan dosen kemudian ditambah dengan lima kompetensi dalam era ini. Usaha untuk mencapai komptensi pendidik dapat diawali dengan perbaikan pada sistem penerimaan pendidik harus selektif, harus dilaksanakan sesuai standar dan kebutuhan teknologi. Seleksi tidak hanya pada aspek intelektual namun harus menguji pada aspek psikologis dan kepribadian pendidik sehingga pendidik siap dalam menghadapi tantangan era revolusi industri 4.0, memfungsikan maksimal kegiatan kelompok kerja guru (KKG) dan musyawarah guru mata pelajaran (MGMP), peningkatan profesi keguruan melalui program peningkatan keprofesian berkelanjutan (PKB)(Wahyuni, 2018).

Upaya nyata dalam menyiapkan calon guru kelas di MI dan SD adalah menyusun kurikulum PGMI di dunia perguruan tinggi yang sesuai dengan kebutuhan calon guru kelas pada era ini. Kurikulum PGMI di pendidikan tinggi harus disesuaikan dengan SNPT dan KKNI. Dalam SNPT diktis disebutkan bahwa profil lulusan prodi PGMI yaitu menjadi guru/pendidik atau praktisi dalam bidang pendidikan, asisten peneliti, dan menjadi pengembang bahan ajar (Ibda, 2018)(Standar Kompetensi Lulusan (SKL) Dan Capaian Pembelajaran Lulusan (CPL) Program Studi Jenjang Sarjana Pada Perguruan Tinggi Keagamaan Islam Dan Fakultas Agama Islam (FAI) Pada Perguruan Tinggi, 2018). Dalam profil lulusan PGMI sebagai pendidik memiliki deskripsi sebagai S.Pd yang memiliki kecakapan dalam bekerja, menguasai pengetahuan, mampu mengelola pendidikan dan bertanggungjawab sebagai guru kelas yang meliputi lima bidang Mapel (mata pelajaran) yang berakhlak, memiliki pengetahuan yang luas dan kekinian serta mampu menjalankan tugasnya bertanggungjawab dengan dasar ajaran dan etika dalam Islam, keilmuan dan keahlian. Profil lulusan program studi PGMI yang ditetapkan diktis sudah 
mencerminkan pendidik masa depan yang sesuai dengan era ini. Setiap lulusan PGMI diharuskan memiliki kemampuan dalam bidang pengetahuan, manajerial, kepribadian, selalu update terhadap perkembangan zaman, dan beretika sesuai Islam.

\section{B. Pembahasan}

Pendidikan harus menyiapkan SDM yang kompeten dan disesuaikan dengan kebutuhan revolusi industri 4.0. Pada era ini menuntut guru termasuk guru kelas di MI dan SD mampu memiliki lima komptensi. Sebagai penghasil calon guru kelas MI dan SD, perguruan tinggi yang membuka program pendidikan bagi calon guru kelas seharusnya mampu menyusun kurikulum agar sesuai dengan lima kompetensi guru kelas di era ini. Dalam penelitian ini penulis berfokus pada kajian tentang peningkatan counselor competence bagi calon guru kelas MI dan SD di era ini yang dilaksanakan lembaga pendidikan tinggi yang menyelenggarakan program pendidikan dasar.

\section{Counselor Competence}

Competence atau kompetensi merupakan perangkat lengkap berupa pengetahuan, kecakapan berupa keterampilan dan sikap berupa perilaku yang harus terinternalisasi oleh guru maupun dosen ketika melakukan tugas keprofesionalan (UU No 14 Tahun 2005, 2005). Sedangkan menurut Lefrancois kompetensi merupakan daya tampung untuk melaksanakan sesuatu yang dihasilkan dari proses belajar(Ma'mur Asmani, 2009). Pemahaman kompetensi yang lain yaitu sebagai seperangkat pengetahuan, sikap, serta keterampilan yang harus dihayati, dikuasai, dan benarbenar diterapkan oleh guru dalam melaksanakan tugas utamanya (Iskandar, Agung, 2014). Berdasarkan pemahaman di atas, penulis memahami bahwa kompetensi merupakan kecakapan seseorang dalam bidang pengetahuan, keterampilan dan sikap yang harus dimiliki oleh orang tersebut untuk melaksanakan semua tugasnya. 
Counselor atau konselor merupakan sesorang yang memberikan bantuan kepada seorang klien dengan menggunakan teknik-teknik konseling (Salahudin, 2010). Yang lain menyebutkan bahwa konseling adalah rangkaian tindakan dalam menolong atau membantu klien untuk memahami, menerima dan membantu kliennya untuk membantu menyelesaikan berbagai permasalahan yang terjadi di dalam hidupnya(Erlina \& Fitri, 2016). Dalam hal ini counselor dipahami sebagai orang yang memberikan bantuan berupa pembimbingan dan pendampingan kepada orang lain yang memiliki permasalahan, agar permasalahan yang dihadapi dibantu untuk diselesaikan. Kompetensi konselor merupakan kecakapan (pengetahuan, sikap dan keterampilan) yang harus dimiliki oleh seseorang untuk membantu orang lain yang mempunyai masalah, sehingga permasalahan yang dihadapi terselesaikan.

Dalam kompetensi konselor, seorang konselor harus memiliki keahlian dan keterampilan baik itu konsep maupun praktis; pertama, pengetahuan terpadu tentang konseling meliputi landasan, asas, prinsip, pengertian, tujuan dan fungsi; kedua, pendekatan, strategi dan teknik melalui berbagai jenis pelayanan dan kegiatan yang mendukung pelayanan konseling; ketiga, menyusun program pelayanan konseling,; keempat, sumber dan media yang dibutuhkan dalam pelayanan konseling,; kelima, penilaian dan evaluasi proses pelayanan konseling, dan; keenam, pengelolaan dalam pelayanan konseling (Penataan Pendidikan Profesional Konselor Dan Layanan Bimbingan Dan Konseling Dalam Jalur Pendidikan Formal, 2008).

Menurut keputusan Pengurus Besar Asosiasi Bimbingan dan Konseling (PB ABKIN) Nomor 10 tahun 2006 tentang penetapan kode etik bimbingan dan konseling (Komalasari, Gantina, 2011). menyampaikan bahwa seorang konselor memiliki kewajiban memenuhi kualifikasi yang terdiri dari: pertama, nilai, pengetahuan, wawasan, keterampilan, nilai, dan sikap; kedua, memperoleh pengakuan atas kemampuan dan kewenangan 
sebagai knselor. Dalam aspek pengetahuan, sikap, keterampilan, nilai, serta wawasan seorang konselor memiliki kewajiban untuk terus mengembangkan diri. Seorang konselor setidaknya memiliki kewajiban mengetahui kekurangan dan prasangka yang ada pada dirinya sendiri yang dapat berpengaruh terhadap orang lain dapat menjadikan mutu dalam pelayanan profesionalnya menjadi rendah, serta dapat merugikan klien. Seorang konselor mempunyai kewajiban memperhatikan karakter low profile, tidak sombong, sabar, menepati janji, jujur, tertib, dan hormat. Seorang konselor mempunyai kewajiban harus memiliki rasa tanggungjawab terhadap pendapat atau peringatan yang diberikan untuknya khususnya dari rekan seprofesinya yang berhubungan dengan tingkah laku yang telah diatur dalam kode etik. Seorang konselor mempunyai kewajiban mengupayakan kualitas kerja yang baik dan selalu mengutamakan kepentingan umum di atas kepentingan pribadi, termasuk dalam kepentingan yang bersifat materi maupun popularitas. Seorang konselor juga mempunyai kewajiban untuk memiliki keterampilan dalam memanfaatkan teknik dan prosedur khusus yang dikembangkan atas dasar wawasan yang luas dan kaidah-kaidah ilmiah.

Terdapat istilah bimbingan, konseling, dan psikoterapi, dari ketiga istilah tersebut sebenarnya menjadi istilah yang sering dipakai secara bersama. Ketiga istilah itu mempunyai makna yang tumpang-tindih dan mempunyai prbedaan yang mndasar. Bimbngan konselng memiliki fokus untuk membantu indvidu dalam mmbuat pilihn hidup yng penting, konseling memiliki fokus membantu individu untuk berubah. Menurut Glading bimbngan secara umum dilaksanakan di sekolah pada jenjang menengah, seorang konselor di sekolah memiliki fungsi untuk membantu para siswa dalam membuat suatu keputusan yang penting di hidupnya, seperti memilih jenjang pendidikan lanjutan atau memilih suatu pekerjaan. Ifat dari bimbingan adalah pencegahan, maksudnya memberikan bantuan untuk seorang individu untuk 
beradptasi dan mencapai proses perkembangnya baik secara pribadi, intelektual, sosial, emosi, dan karirnya (Komalasari, Gantina, 2011).

Istilah konseling diperuntukan bagi individu yang normal, sedangkn psikoterapi ditujukkan bagi seorang indiviidu yang mengaalami ganggguan dalam psikologisnya. Sifat dari konseliing yaitu edukatiif, suportiif, dan memiliki orientasi pada kesadaran serta pelaksanaan yang relative singkat. Sedangkan sifat dari Psikoteraapi yaitu membangung kembali, konfrontatif, memiliki orientasi pada ketidak sadaran, dan dilaksanaakan dalam jangka waktu yang lama. Konseling lebih terstruktur, diarahkn pada tujuan yang memiliki batas, sedangkan psikoterapii bertujuaan mengubah diri seorang indiividu.

Bahwa dalam kompetensi konselor harus sangat diperhatikan beberapa tugas dan kewajiban yang sudah tercantum di kode etik konselor. Namun, kebutuhan di era sekarang yang memang semakin banyak problem yang dihadapi manusia harusnya semakin banyak pula kebutuhan akan jasa seorang konselor. Konselor merupakan sebuah profesi yang harus memiliki sertifikat profesional dari lembaga terkait. Keberadaan konselor yang bersertifikat di Indonesia masih belum mencukupi kebutuhan, padahal setiap lembaga pendidikan harus memiliki minimal satu orang yang memiliki kompetensi sebagai konselor untuk bisa mengatasi problematika yang dihadapi oleh peserta didik.

\section{Calon Guru Kelas MI Dan SD Di Era Revolusi Industri 4.0}

Tujuan institusional sekolah dasar yaitu agar setiap siswa dapat mengembangkan kemampuan, minat dan nilai dalam pandangan hidupnya secara optimaal. Era ini sangat berpengaruh pada berbagai sektor. Perkembangan bidang ICT yang serba canggih mengakibatkan dunia terasa sempit. Berbagai informasi dari seluruh dunia dengan mudah diakses dengan instant oleh siapapun, darimanapun. Begitu juga komunikasi antar individu 
dapat dilakukan dengan murah dan mudah. Adanya revolusi industri 4.0 kenyataannya tidak terlalu berpengaruh signifikan terhadap tiga profesi yaitu guru, dokter dan perawat serta seniman. Guru berperan membangun generasi yang berkompeten, berkarakter, memiliki keterampilan berpikir tingkat tinggi dan memiliki kemampuan literasi baru. Peran guru sebagai orang tua di sekolah yang meliputi mendidik, mengajar dan membimbing tidak dapat sepenuhnya digantikan oleh kecanggihan teknologi. Teknologi tidak bisa memberikan sentuhan khas seorang guru.

Semakin berkembangnya zaman dengan berbagai kemudahan yang didapatkan seorang pendidik tidak boleh terlena dengan kondisi yang demikian. Keberhasilan Indonesia dalam menghadapii era ini ditentukn juga oleh kualitass masingmasing pendididik. Seorang pendidik atau guru diharuskan untuk menguasaai berbagai keaahlian, mampu menyesuaikan diri serta mampu memprediksi perkembangan teknologi baru dan berbagai macam tantangan global. Oleh sebab itu, pendidik atau guru harus terus memperbaharui keterampilannya dan kemampuannya agar sesuai dengan tuntutan zaman serta mampu menghasilkan SDM yang berkualitas.

Era ini mampu mengubaah cara pandaang tentang pendiidikan. Bukan lagi perubahan cara mengajar, tetapi perubahann terhadap cara memandang konsep pendididkan yang setidaknya mampu menyiapkan siswanya dalam tiga hal. Ketiga hal tersebut adalah menyiapkan siswa untuk dapat berkerja padaa jenis profesi yang pada waktu ini belum tersedia, menyiapkann siswa agar mampu memecahkan permasalahan yang pada waktu ini belum muncul serta menyiapkan siswa agar mempu menggunakan tenkologi yang pada saat ini belum ditemukan. Guru masa depan akan menghadapi bahan ajar yang lebih rumit, standar belajar mengajar yang tinggi serta target capaian kemmampuan siswa dalam berpikir tingkat tingggi. Hal lain yang harus diperhatikan adalah mereka akan menghadapi siswa yang lebih beragam.

Elementary Vol. 8 No. 1 Januari - Juni 2020 
170 | Roikhatul Janah dan Dhiya Ayu Tsamrotul Ihtiari

Graeme Codrington \& Sue Grant-Marshall (Sukri Syamsuri, n.d.) membedakan lima generasi manusia berdasarkan tahun kelahiranya. Adapun 5 genearasi manusia tersebut yaitu: (1) Baby Boomer, adalah generasi yang diisi oleh manusia yang terlahir di tahun 1946 - 1964; (2) X, adalah generasi yang diisi oleh manusia yang terlahir di tahun 1965 - 1980; (3) Y atau sering disebut generasi milenial adalah generasi yang diisi oleh manusia yang terlahir di tahun 1981 - 1994 ; (4) Z, atau disebut juga iGeneration, GenerasiNet, Generasi Internet, adalah generasi yang diisi oleh manusia yang terlahir di tahun 1995 - 2010; (5) Alpha, adalah generasi yang diisi manusia terlahir di tahun 2011 - 2025. lima generasii manusia tersebut memilliki perbedaan dalam hal tumbuh kembang kepribadian. Berdasarkan teori generrasi manusia ini, maka siswa usia MI/SD pada saat ini termasuk dalam generasi alpha. Sejak lahir generasi alpha sudah kenal dan erat berhubungan dengan teknologi yang canggiih. Oleh karena itu, bisa dibayangkan bagaimana dekatnya generasi alpha dengan dunia maya. Generasi alpha juga sangart terdidiik karena kesadaran orang tua untuk memasukkan anaknya lebih awal, sehingga kesempatan anak untuk belajar menjadi lebih lama, serta di dukung dengan orang tua yang memiliki kecukupan biaya untuk pendidikan.

Untuk menjawab tantangan di era ini, lembaga pendidikan dasar Islam seharusnya tidak cukup jika hanya mengimplementasikan literasi lama (membaca, menuilis, dan brhitung), namun harus juga mengimplementasikan literasi baru (leterasi data, teknologi, SDM/humaniisme). Oleh karena itu, dalam upaya mewujudkan generasi yang memiliki kompetensi yang tinggi dalam menjawab tantangan era ini, guru dalam ranah pendididkan dasar Islam harus mampu menjadi guru digital, memahami komputer, dan tidak memiliki penyakit akademis (Ibda \& Rahmadi, 2018).

Profesionalitas guru dalam menjalankan kegiatan pendidikan dan pengajaran tidak dapat dipisakan dengan 
kompetensi. Organisasi dunia dalam bidang pendidikan UNESCO menyebut ada kompetensi penting di abad ke-21 ini. Kompetensi bagi guru yang dimaksud UNESCO tersebut adalah kompetensi Information Communication and Technology (ICT). Mengingat persaingan yang semakin sengit, maka profesi guru juga harus dikembangkan sesuai perkembangan jaman. Menurut Riskha kompetensii guru yang dibutuhkan pada era ini antara lain seorang guru harus mempunyai kompetensi pendidikan (educational competence), kompetensi mengkomersilkan teknologi (competence for technological commercialization), kompetensi globalisasi (competence in globalization), kompetensi strategi menghadapi masa depan (competence in future strategies), dan kompetensi konselor (counselor competence)(Fitriyah, 2019). Adapun penjelasan dari lima kompetensi guru di era ini adalah sebagai berikut:

\section{a. Educational Competence}

Educational competence adalah kompetensi belajar mengajar berdasarkan pada internet yang dijadikan ketrampilan dasar (basic skill). Kehadiran Internet of Things (IoT) sudah menjadi bagian dari kehidupan manusia. Maka dari itu, penguasaan berbagai peralatan berbasis IoT mutlak harus dikuasai guru. Contoh nyata yang harus dilakukan guru terkait penggunaan IoT adalah memberlakukan pembelajaran secara elektronik atau e-learning. Karena itulah, seorang guru harus memperbaharui kompetensinya, dengan cara membiasakn diri terhadap bermacam-macam alat yang tterhubung dengan IoT dalam proses belajar mengajar.

\section{b. Competence for technological commercialization}

Diharapkan guru mempunyai kompetensi dalam mengkomersialisasikan teknologi ke luar sekolah. Komersialisasi teknologi yang baru ditemukan oleh guru dapat memiliki dampak yang cukup signifikan 
172 Roikhatul Janah dan Dhiya Ayu Tsamrotul Ihtiari

terhadap pertumbuhan ekonomi, ilmu pengetahuan \& teknologi. Maka seorang guru sudah seharusnya memiliki kompetensi yang nantinya siswa dapat mempunyai sikap enterpreunership dengan teknologi yang menjadi penemuan baru milik mereka sendiri.

c. Competence in globalization

Seorang guru diharapkan melek terhadap bebagai budaya dan mampu menyelesaikan permasalahan pendidikan. Bahwa tidak dapat dipungkiri kebabasan akses internet dapat mempercepat arus globalisasi, sehingga seorang guru harus mampu menanggapi kecepatan akses tersebut dengan memberikan informasi-informasi terkini di seluruh dunia kepada peserta didik.

d. Competence in future strategies

Competence in future strategies diartikan suatu kompetensi digunakan dalam melakukan prediksi dengan tepat tentang apa yang akan terjadi di masa yang akan datang serta strategi penanganannya. Ketidakmampuan manusia dalam menebak kejadian masa depan setidaknya dapat diantisipasi dengan kemampuan setiap individu untuk memprediksi kemungkinan yang akan terjadi. Upaya yang dapat dilakukan yaitu melanjutkan studi ke jenjang pendidikan yang lebih tinggi, melaksanakan riset, memaksimalkan sumber daya yang ada secara bersama, staff mobility dan rotasi. Dengan demikian, perkembangan sekolah di Indonesia tidak jauh tertinggal dari isu global dalam dunia pendidikan.

e. Counselor competence

Counselor competence yaitu komptensi guru untuk memahami bahwa di masa depan permasalahan siswa bukan sekedar tentang kesulitan dalam pemahaman tentang pelajaran, namun berkaitan juga dengan masalah psikologis yang diakibatkan perkembangan zaman. 
Peningkatan Counselor Competence bagi Calon Guru ..... |173

Seorang guru harus mampu menjadi konselor untuk siswanya dalam upaya penyelesaian permasalahan yang dihadapinya.

Pada era ini counselor competence tidak khusus hanya untuk guru BK. Lebih luas lagi kompetensi konselor harus dimiliki oleh setiap guru, baikitu guru mapel atau guru kelas dijenjangpendidikan dasar. setiap guru dimungkinkan akan menghadapi siswa dalam pembelajaran dengan kondisi permasalahan yang berbeda-beda, sehingga kompetensi konselor harus dimiliki oleh setiap guru. Sama pentingnya dengan calon guru, mereka harus mendapatkan bekal pengetahuan dari perguruan tinggi masing-masing agar nantinya calon guru tersebut mampu mengaplikasikan pengetahuannya tentang konseling kepada siswanya.

Guru kelas di MI dan SD merupakan guru yang bertanggungjawab penuh atas semua kegiatan dan kondisi siswanya di kelas. Guru kelas dituntut mampu menghadapi dan mencarikan solusi dari segala macam permasalahan yang terjadi di kelasnya sehingga kelas yang diampu tercipta iklim kelas yang kondusif. Dengan tanggung jawab dan tuntutan revolusi industri 4.0 yang begitu besar, maka sudah sewajarnya jika calon guru kelas di MI atau SD harus mendapatkan pengetahuan yang berkaitan dengan bimbingan dan konseling bagi siswanya. Dalam kemampuan manajerial yang terdapat dalam KKNI guru kelas MI/SD harus mampu memberikan arahan serta langkah efektif untuk mengatasi berbagai pemecahan masalah dalam bidang guru kelas MI/SD. Sudah menjadi keharusan dalam perkuliahan di pendidikan dasar bahwa calon guru kelas harus dibekali ilmu tentang bimbingan dan konseling dan psikologi perkembangan.

\section{Upaya Peningkatan Counselor competence Bagi Calon Guru Kelas MI Dan SD Di Era Revolusi industri 4.0}

Kecepatan teknologi yang terjadi pada era ini, akan membawa perubahan yng cukup signifikan, begitu juga dengan pendidikan. Perkembangan teknologi dalam 10 tahun terakhir sangat pesat membuat segala sesuatu memiliki pola baru dalam 
174 | Roikhatul Janah dan Dhiya Ayu Tsamrotul Ihtiari

implementasinya. Dalam dunia pendidikan tahun 2013 menjadi tahun pergantian kurikulum lama (KTSP) menjadi kurikulum baru (K13). Akibat pergantian kurikulum tersebut segala aspek dalam pendidikan berubah secara perlahan. Mulai dari sistem pembelajaran yang berdasarkan tematik dengan pemanfaatan teknologi, sampai pada sistem evaluasi yang mengharuskan guru untuk menilai siswanya dengan menggunakan sistem online. Tugas guru semakin berat dengan segala sesuatunya harus dimasukkan dalam sistem yang terhubung dalam big data kementerian pendidikan maupun kementerian keagamaan. Begitu juga dengan siswanya, siswa juga dituntut untuk semakin mengikuti perkembangan zaman, dalam kondisi sosial ekonomi apapun seorang siswa harus mampu mengikuti sistem pembelajaran yang berbasis teknologi. Tugas seorang gurulah untuk mengajarkan siswanya untuk belajar mengikuti arus perkembangan zaman. Calon guru kelas di era revolusi industri bukan hanya guru yang lolos uji kemampuan intelektual saja, namun harus lolos uji kemampuan psikologis dan kepribadian sehingga segala tantangan revolusi industri berhasil dihadapi.

Dalam kurikulum pendidikan dasar rata-rata mahasiswa pendidikan dasar akan mendapatkan mata kuliah psikologi perkembangan peserta didik dan mata kuliah bimbimngan dan konseiling. Pada mata kuliah tersebut harus terinternalisasi dengan baik, sehingga lulusan pendidikan dasar kompeten dalam bidang konseling.

Kompetensi sebagai konselor menjadi penting dimiliki oleh setiap calon guru kelas di MI atau SD karena dengan siswa-siswa pada pendidikan dasar merupakan siswa-siswa pada generasi alpha yang memang era literasinya sangat berbeda dengan era literasi pada zaman calon gurunya. Di generasi alpha siswa akan memiliki waktu yang sangat lama untuk berselancar dengan gawai di berbagai kondisi. Siswa akan lebih mudah mencari atau mempelajari sesuatu lewat gawainya. Dengan kondisi tersebut tentunya akan sangat membahayakan psikologis siswa itu sendiri. 
Berdasarkan keterangan seorang psikolog Elly Risman dalam acara Indonesia Lawyers Club yang tayang pada salah satu stasiun televisi swasta, bahwa anak-anak akan mengalami penyusutan otak depan sebesar 4,4\% otak bagian depan merupakan otak yang membedakan manusia dengan hewan(Ilyas, 2019). Peristiwa tersebut menyebabkan anak-anak akan kehilangan kontrol diri, sehingga apa yang dilihat digawainya masing-masing akan dipraktikkan dalam kehidupan nyata tanpa kontrol. Apabila anakanak tidak bisa mempraktikkan apa yang dilihat digawainya dalam kehidupan nyata maka anak-anak akan memiliki kemungkinan mengalami gangguan emosi. Berdasarkan data dari Rumah Sakit Jiwa (RSJ) di Jawa Barat mencatat sejak 2016 ada 209 anak yang dirawat terkait adiksi internet dan games. Rata-rata tiap bulan ada sekitar 10 sampai 12 anak dengan usia berkisar 8- 15 tahun yang mengikuti rawat inap/jalan di RSJ Jawa Barat Cisarua Kabupaten Bandung Barat (voaindonesia.com). World Health Organization (WHO) telah memasukkan kategori kecanduan internet sebagai gangguan kejiwaan. Betapa fakta tersebut telah membuat orang tua harusnya lebih teliti dalam pengawasan terhadap anaknya terkait penggunaan gawai. Selain itu lembaga pendidik juga mempunyai peran yang sangat pentieng dalam menyeimbangkan teknologi dann ilmu pengetahuan, agar siswa bisa lebih bijak dalam menggunakan gawai. Kebebasan akses sekarang memang sudah kelewat batas, bisa dikatakan tidak ada satupun peserta didik yang tidak bisa mengoprasikan gawai canggih, dan menggunakannya bisa jadi tanpa kontrol dari orang tua. Maka, kelewat batas yang demikian masuk dalam tugas guru sebagai orang yang diamanahi di sekolah untuk mampu memberikan bimbingan dan konseling kepada siswa yang terpapar adiktif dari gawai.

Calon guru kelas di MI atau SD harus mampu memiliki kompetensiguruyangsesuaidenganerainiyaituterinternalisasinya 5 kompetensi guru pada semua kegiatan perkuliahan yang diikuti oleh mereka yang kuliah di fakultas/jurusan pendidikan. Lima kompetensi guru di atas harus dimasukkan dalam kurikulum 
perguruan tinggi yang memiliki fakultas atau jurusan pendidikan. Begitu halnya dengan prodi pedidikan dasar, calon guru kelas harus diajarkan lima kompetensi guru yang sesuai dengan era ini.

Untuk membentuk calon guru yang memiliki kompetensi konselor, maka perguruan tinggi yang menyelenggaran program pendidikan bagi calon guru harus menyajikan kurikulum yang memenuhi apa yang diperlukan. Adapun profil lulusan dari program studi PGMI yang disusun oleh Dirjen Pendidikan Islam Kementerian Agama menyebutkan bahwa profillulusan prodi PGMI harus menjadi pendidik yang mempunyai etos kerja, menguasai ilmu pengetahuan, kemampuan mengelola dan tanggungjawab sebagai pendidik guru kelas. Kemampuan manajerial inilah yng menjadikan seorang guru kelas harus mampu mengelola kelas mulai dari perencanaan pembelajaran, pembelajaran, evaluasi, sampai pada kondisi siswa. Guru kelas harus mampu menjadi yang pertama dan utama dalam memecahkan berbagai problematika yang siswa alami yang dapat mengganggu proses kegiatan belajar mengajar.

Kurikulum di prodi PGMI harus menuntut calon guru kelas memiliki kemampuan manajerial agar calon guru kelas mampu memberikan arahan serta langkah efektif untuk mengatasi berbagai pemecahan masalah dalam bidang guru kelas MI/SD secara mandiri dan bersama-sama untuk mendapatkan hasil belajar mengajar yang berkualitas dan dalam pembentukkan perilaku keagamaan peserta didik mencapai nilai maksimal. Seorang calon guru kelas juga harus memiliki keterampilan umum agar mampu dengan tepat ketika mengambil keputusan, dalam perihal menyelesaikan masalah dalam bidang keahliannya atas dasar analisis yang dilakukan melalui informasi dan data yang dimiliki.

Calon guru kelas akan sangat mungkin menjumpai situasi dimana kelas yang ditangani akan memiliki masalah yang rumit, maka harus dibekali pengetahuan yang dapat memaksimalkan kemampuan manajerial dan keterampilan umum. Agar masalah 
yang ada dapat diselesaikan dengan tepat. Jika mengacu pada SKL dan CPL yang disusun oleh Dirjen Pendidikan Islam Kementerian Agama Republik Indonesia, maka susunan SKL dan CPL tersebut sudah sangat mendukung calon guru kelas di MI/SD untuk memiliki kompetensi sebagai konselor. Kompetensi konselor harus diinternalisasikan kepada calon guru kelas melalui mata kuliah bimbingan dan konseling yang jumlah SKS - nya harus disesuaikan dengan Capaian pembelajaran yang harus diperoleh oleh calon guru kelas MI/SD. Sehingga dengan tercapainya kompetensi konselor maka seorang guru kelas akan mampu menyelesaikan situasi rumit yang akan terjadi ketika sudah menjadi guru kelas.

\section{Simpulan}

Era revolusi industri 4.0 menuntut calon guru/pendidik harus memiliki 5 kompetensi, adapun lima kompetensi tersebut yaitu, educational competencee, competence for technological commercialization, competence in globalization, competence in future strategies, counselor competence. Kompetnesi konselor mrupakan kemampaun (pengetahuan, sikap dan keterampilan) seseorang untuk membantu orang lain yang mempunyai masalah, sehingga permasalahan yang dihadapi terselesaikan. Menjadi sangat penting jika seorang calon guru kelas di MI/SD harus mampu memiliki kompetensi ini.

Perguruan tinggi pelaksana program pendidikan dasar harus mampu mengemas dan menyajikan kurikukum bagi mahasiswa calon guru kelas MI/SD agar memiliki kompetensi konselor. Direktorat Pendidikan Islam Kementerian Agama telah membuat SKL dan CPL bagi Prodi PGMI yang memuat semua kompetesi harus dimiliki oleh guru kelas MI/SD. SKL dan CPL tersebut memuat kompetensi manajerial dan kemampuan umum yang harus dicapai oleh calon guru kelas MI/SD yaitu; calon guru kelas harus mampu memberikan arahan serta langkah efektif untuk mengatasi berbagai pemecahan masalah dalam bidang 
178

Roikhatul Janah dan Dhiya Ayu Tsamrotul Ihtiari

guru kelas MI/SD secara mandiri dan bersama-sama untuk mendapatkan hasil belajar mengajar yang berkualitas dan dalam pembentukkan perilaku keagamaan peserta didik mencapai nilai maksimal. Seorang calon guru kelas juga harus memiliki keterampilan umum agar mampu dengan tepat ketika mengambil keputusan, dalam perihal menyelesaikan masalah dalam bidang keahliannya atas dasar analisis yang dilakukan melalui informasi dan data yang dimiliki.

Kompetensi pengelolaan dan keterampilan umum yang harus dimiliki calon guru kelas MI/SD tersebut harus sesuai dengan kebutuhan seorang guru di era ini yaitu counselor competence, sehingga calon guru kelas MI/SD yang berasal dari perguruan tinggi keislaman sangat mampu menjadi guru kelas yang menjawab tantangan revolusi industri 4.0. 


\section{DAFTAR PUSTAKA}

Depdikbud. Penataan Pendidikan Profesional Konselor Dan Layanan Bimbingan Dan Konseling Dalam Jalur Pendidikan Formal, 2008.

Direktorat Jendral Pendidikan Islam Kementerian Agama Islam Republik Indonesia. Standar Kompetensi Lulusan (SKL) Dan Capaian Pembelajaran Lulusan (CPL) Program Studi Jenjang Sarjana Pada Perguruan Tinggi Keagamaan Islam Dan Fakultas Agama Islam (FAI) Pada Perguruan Tinggi, 2018.

Erlina, N., \& Fitri, L. A. Penggunaan Layanan Konseling Individu dengan Pendekatan Behavioral untuk Mengurangi Prilaku Membolos Peserta Didik Kelas VIII MTs Miftahul Ulum Merabung Iii Kecamatan Pugung Kabupaten Tanggamus. KONSELI: Jurnal Bimbingan Dan Konseling (E-Journal), 2016.

Fitriyah, R. N. Pengembangan Kompetensi Guru di Era Revolusi Industri 4.0 melalui Pendidikan dan Pelatihan. Prosiding Sendi, 2019.

Ghufron, M. A. Revolusi industri 4.0: Tantangan, Peluang dan Solusi Bagi Dunia Pendidikan. Seminar Nasional Dan Diskusi Panel Multidisiplin Hasil Penelitian Dan Pengabdian Kepada Masyarakat, 2018.

Ibda, H. PENGUATAN LITERASI BARU PADA GURU MADRASAH IBTIDAIYAH DALAM MENJAWAB TANTANGAN ERA REVOLUSI INDUSTRI 4.0. JRTIE: Journal of Research and Thought of Islamic Education, 1(education), 1-21. https:// doi.org/10.24260/jrtie.v1i1.1064, 2018. 
180 | Roikhatul Janah dan Dhiya Ayu Tsamrotul Ihtiari

Ibda, H., \& Rahmadi, E. Penguatan Literasi Baru pada Guru Madrasah Ibtidaiyah dalam Menjawab Tantangan Era Revolusi Industri 4.0. JRTIE: Journal of Research and Thought of Islamic Education, 2018.

Ilyas, K. Indonesia Lawyers Club, 2019.

Iskandar, Agung, D. Mengembangkan Profesionalitas Guru Upaya Meningkatkan Kompetensi Dan Profesionalisme Kinerja Guru. Bae Media Pustaka, 2014.

Kementrian Pendidikan Nasional. 7 Provinsi Raih Nilai Terbaik Uji Kompetensi Guru 2015. https://www.kemdikbud.go.id/ Main/Blog/2016/01/7-Provinsi-Raih-Nilai-Terbaik-UjiKompetensi-Guru-2015, 2015.

Komalasari, Gantina, D. Teori dan Teknik Konseling. Indeks, 2011

Krjogja. Guru Era 4.0. http://krjogja.com/Web/News/ Read/59981/Guru_Era_4_0, 2018.

Lase, D. Pendidikan di Era Revolusi Industri 4.0. SUNDERMANN Jurnal Ilmiah Teologi Pendidikan Sains Humaniora Dan Kebudayaan. https://doi.org/10.36588/sundermann. v1i1.18, 2019.

Ma'mur Asmani, J. 7 Kompetensi Guru Menyenangkan Dan Profesional. Power Books (Ihdina), 2009.

Nazir. Metode Penelitian. Metode Penelitian, 2004.

Republik Indonesia. Undang-Undang Nomor 14 Tahun 2005 tentang Guru dan Dosen. Sekretariat Negara, 2005. 
Salahudin, A. Bimbingan dan Konseling. Pustaka Setia, 2010.

Shelley, M., \& Krippendorff, K. Content Analysis: An Introduction to its Methodology. Journal of the American Statistical Association. https://doi.org/10.2307/2288384, 1984.

Sukri Syamsuri, A. D. I. (n.d.). Guru, Generasi Z, Dan Pembelajaran Abad 21. http://www.unismuh.ac.id/Wp-Content/ Uploads / 2018/05/Tantangan-Guru-Generasi-Z-DanPembelajaran-Abad-21.Pdf.

UU No 14 Tahun 2005, R.. Undang-undang Guru dan Dosen. Produk Hukum. https://doi.org/http://dx.doi.org/10.1016/ S0167-2991(08)63816-1Wahyuni, D. (2018). Peningkatan Kompetensi Guru Menuju Era Revolusi Industri 4.0. Info Singkat (Kajian Singkat Terhadap Isu Aktual Dan Strategis) Pusat Penelitian Badan Keahlian DPR RI 2018, 2005.

Yunus, S. Mengkritisi Kompetensi Guru. Detik.Com. https://news. detik.com/Kolom/D-3741162/Mengkritisi-KompetensiGuru, 2018 
182 Roikhatul Janah dan Dhiya Ayu Tsamrotul Ihtiari 